\title{
Troleybüs Problemi
}

\section{The Trolley Problem}

\author{
Vedat Menderes ÖZÇİFTCİ
}

\section{Thomas Cathcart, "TROLEYBÜS PROBLEMİ ya da Şişman Adamı Üst Geçitten Aşă̆ı Atar mısınız? FELSEFİ BIR MUAMMA", Çevirmen: İbrahim Şener, Ekim 2016, 1. Baskı, 144 sayfa. Pegasus Yayınlar}

Kontrolden çıkmış bir vagon hızla ilerlemektedir. Az ilerinizde, rayların üzerinde beş iş̧̧i çalışmakta, yan hatta ise bir işçi. Siz bu vagonu kontrol eden kişi olsaydınız, beş kişiyi öldürmeyi göze alır mıydınız yoksa bir kişiyi mi kurban ederdiniz? Veya sürücü değil de tüm bu olaylara kenardan tanık olan biri iseniz ve elinizdeki bir makasla vagonun yönünü değiştirebilecek olsanız? Makası bir işçi yönünde çevirmek için kullanır mıydınız? Ya da bir üst geçitten olaya tanıklık ediyorsunuz. İşçileri kurtarabilmenin tek yolu, vagonun önüne ağır bir nesnenin düşmesi ve yanınızda çok şişman bir adam var. Peki şimdi ne yapardınız?

Başkalarının hayatını kurtarmak için bir hayattan ödün vermek mümkün olan en iyi sonuç mudur? Temel yaşam hakkının kutsallığı, en fazla sayıda insan için en büyük iyiliği gerçekleştirmenin faydasına baskın çıkabilir mi? Masum bir insana zarar vermek, eylemlerimizin niyeti değil de öngörülebilir bir sonucuysa, bunu nasil yargilarız?

Bundan elli yıl kadar önce ilk kez bir İngiliz dergisinde yayınlanmış olan bir düşünce deneyi (1), filozofların ilk çağdan beri yaptıkları gibi, soru üzerine sorulara neden olmuş; modern felsefenin belki de en merak uyandırıcı ve biraz tuhaf düşünce deneyi olarak literatürde yerini almıştır. "TROLEYBÜS PROBLEMİ ya da Şişman Adamı Üst Geçitten Aşağı Atar mısınız? FELSEFİ BİR MUAMMA" kitabı ile Thomas Cathcart, gündelik hayatta her an karşılaşabileceğimiz bir senaryo üzerinden ahlak felsefesi tarihi içerisinde eğlenceli ve bilgilendirici bir tura çıarıp bir garip etik ikilemin hikayesini bizlere anlatıyor.

Kitap birbiri ile ilintili olarak devam eden 15 bölümden oluşmakta. Bu 15 bölüm boyunca Cathcart, kendi senaryosu üzerinden filozoflar, psikologlar ve hatta beyin bilimcilerin bu felsefi bilmecenin çeşitli varyasyonları arasında ahlaki kararlarımızın doğasını anlamaya çalışmalarının serüvenini aktarırken; 20. Yüzyıl felsefesinin ilerleyişini bu problem yoluyla tekrardan ortaya koyuyor. Etik profesyonellerinin çok yakından bildiği fakat genel okuyucu kitlesi ve etik alanına yeni adım atmış öğrenciler için yeni sayılabilecek düşünür ve görüşler kitap boyunca ek açıklama bölümleri ile okuyucuya tanıtılmış. Gerçek hayattaki etik konu ve kararlar daha zengin ve karmaşık olmasıyla birlikte, görece basit düşünce deneyleri yöntemi aydınlatmak konusunda yardım sağlayabilir. Bu açıdan da kitap, etik alanında yol almaya yeni başlayanlar için iyi bir başlangıç niteliğine sahip.

Bilim tarihine göre kısa bir zamandan beri ele alınmakta olmasına rağmen, ahlaki karar verme süreçlerinin sinirbilim tarafından araştırılmasının 21. Yüzyılda ortaya koyduğu sonuçlar, felsefe geleneğinin kadim sorularına yepyeni bakış açıları getirmekte. Yazar, bu ikilemin aydınlatılması yolundaki yeni çalışmaları ve sonuçlarını kitabında gözardı etmemiş; bu çok disiplinli yeni bakış açılarını okuyucusunun ilgisine sunmuş. Kitabın son bölümünde ise kurgu boyunca kullanmış olduğu düşünce argümanlarının esas metinlerini bölümler sırasıyla 
listeleyerek, ahlaki ikilemler konusunda daha ileri okumalar yapmak isteyen okuyucuya bir yol haritası da sunmuş.

Şişman adamı üst geçitten aşağı atın ya da atmayın; Troleybüs Problemi doğru, yanlış, etik ve ahlak dörtgeninde bilimin yürüdügü yola ışık tutması sebebiyle günümüzde de tartışılmaya devam edecektir. Bu kitapla konuya ilgi duyanlar etiğin bu ilgi çekici alanı içerisinde, kendilerine yeni bir perspektif edinebilirler.

Thomas Cathcart (1940-): 1961 yllinda Harvard College'den felsefe derecesiyle mezun olan yazar, The University of Chicago Divinity School, McCormick Theological Seminary ve Bangor Theological Seminary gibi kurumlarda teoloji eğitimi almıştır. Üniversite okutmanlığı ve hospis yöneticiliği gibi alanlarda çalıstıktan sonra, Daniel Klein ile birlikte yazdığı, uluslararası alanda çok satanlar listesine giren ve dilimize Pegasus Yayınları aracılığıyla kazandırılmış olan "Platon Bir Gün Kolunda Bir Ornitorenkle Bara Girer" adlı kitabıyla yazarlık kariyerine başlamıştır. Yazarın Daniel Klein ile birlikte temel felsefi konuları mizahi bir dil ile aktardıkları, "Nietzsche Öldü! Bir Hipopotam Olarak Yeniden Doğdu" ve "Aristoteles ve Bir Karmcayiyen Washington'a Gider" adlı iki kitabı daha bulunmaktadır.

\section{Kaynaklar}

1) Foot P. The Problem of Abortion and the Doctrine of the Double Effect. Oxford Review. 1967;5:5-15. 